\title{
Comparative Study between the Use of the Radial Artery and the Saphenous Vein in Coronary Artery Bypass Surgery
}

Hany Elrakhawy ${ }^{1}$, Mohamed Saffan ${ }^{1}$, Ahmad Ghonim ${ }^{1,2}$, Moataz Rizk ${ }^{1}$, Ashraf Elnahhas ${ }^{1}$, Mahmoud Elshafea ${ }^{1}$, Ehab Fawzy $^{1}$, Ahmed Sobhi ${ }^{1}$, Mahmoud Ghalwash ${ }^{1}$, Tamer Khattab ${ }^{1}$, A Elsebaeyshousha ${ }^{3}$ Marwan Sadek $^{4}$ and Mohamed Alassal $^{1^{*}}$

${ }^{1}$ Benha University, Faculty of Medicine, Cardiothoracic Surgery Department, Egypt

${ }^{2}$ Nasser institute, cardiac surgery department, Cairo, Egypt

${ }^{3}$ Alazhar university, Faculty of Medicine, Cardiothoracic Surgery Department, Egypt

${ }^{4}$ King Fahad Military Medical Complex, Dhahran, KSA

Received: May 16, 2018; Accepted: May 29, 2018; Published: May 31, 2018

*Corresponding author: Mohamed Abdelwahab Alassal, Assistant professor and consultant of cardiothoracic surgery, Benha Faculty of medicine, Egypt, E-mail: dmohamedabdelwahab@gmail.com

\begin{abstract}
Background: This study was done to compare between the use of the radial artery and the great saphenous vein when they are used as conduits for the obtuse marginal artery during coronary artery bypass surgery.
\end{abstract}

Methods: 60 patients in need for coronary artery bypass surgery were included in this study (CABG). The left internal thoracic artery (LITA) was used regularly as a conduit for the left anterior descending artery (LAD) in all of them. The radial artery (RA) was used as a conduit for the obtuse marginal artery (OM) in 30 patients, and in the other 30 patients the great saphenous vein (SVG) was used to graft the obtuse marginal artery. Both of them (the radial artery and the great saphenous vein) were used as aortocoronary bypass. All the patients were assessed for the primary outcomes as postoperative bleeding, reopening, arrhythmia, low cardiac output, angina, myocardial infarction, ICU stay, wound complications, hospital stay and death Electrocardiogram and echo was done for all patients 2 weeks, 3 months and 6 months after surgery.

Results: There is no myocardial infarction, angina, and postoperative electrocardiogram and echo abnormalities in both groups. Postoperative bleeding was more common in the radial artery group, and leg wound infection was more common in saphenous vein group.

Conclusion: Short term results of both (the radial artery and SVG) are the same when they are used as conduits to bypass lesions in the obtuse marginal artery during cardiopulmonary bypass surgery. More studies are needed to assess the long term results.

Keywords: Radial artery; Saphenous vein; Coronary artery bypass

\section{Introduction}

In 1964, Kolesov grafted LITA to the circumflex artery on a beating heart using a collapsible cannula to create the anastomosis without interruption of coronary blood flow. By October 1967, René Favolaro, using the saphenous vein, reported 180 cases of coronary artery bypass surgery, starting CABG program in Cleveland Clinic, and the CABG surgery as a new and only treatment for coronary artery disease at that time, before PCI was invented [1].

With technical simplicity in harvesting and handling the saphenous vein, it became the main conduit to be used in CABG. Discovering that the vein is more prone to develop intimal hyperplasia, atherosclerosis, and graft thrombosis, in 1986, Floyd Loop and the Cleveland Clinic group reported that the use of ITA, compared to the use of the vein grafting alone, was associated with improved early and late clinical results [2].

With this observation surgeon started to look for other arterial conduits, believing that they will have the same advantages of ITA. So the gastroepiploic artery was first used in 1987, and the inferior epigastric artery in 1990, but their use was associated with some technical difficulties. The radial artery was first used by Carpentier in 1971, but he discontinued its use after early disappointing results, but its use was revived by Acar in 1992 using more refined measures in radial artery harvesting, and using pharmacological rather than mechanical dilatation [3].

The radial artery (RA), by definition, is a type III artery, which are arteries to limbs. They contain more smooth muscle cells in their walls and are therefore less elastic. They are muscular arteries and more prone to vasospasm because of their higher contractility [4]. Radial arteries have been shown to be associated with a higher degree of arteriosclerosis than the internal thoracic artery, and the presence of vessel calcification, the most common pathology of radial arteries would also preclude its use for CABG. It is reported that RA is not an ideal conduit to bypass target arteries that indicate less critical $(<70 \%)$ stenosis because of the possibility of competitive flow that results in either complete occlusion or formation of "string sign" [5].

It has been reported that saphenous veins used as aortocoronary conduits develop intimal hyperplasia, followed by atheromatous change. This characteristic has been proved histologically and is responsible for the poor long-term results [1]. 
Radial artery grafting is used in only $9 \%$ of patients undergoing $\mathrm{CABG}$ as noted in the Society of Thoracic Surgeons database. Thus, the vast majority of patients presently undergoing CABG in the United States receive only one arterial graft, the LITA, and SV grafts [6]. As the LITA is proved to be the golden conduit for the left anterior descending artery (LAD), the second best conduit with LITA is still unclear. Some believe in the superiority of SVG over the radial artery specially when no touch technique is applied, [7] others believe that the radial artery patency is at least comparable to that of the saphenous vein, [8-9] others support the use of the radial artery as they believe that it improve long term survival compared with using the LITA and SVG [10]

\section{Patients and methods}

After obtaining approval by the Benha University Hospital Ethics Committee, and written informed consent from the patient, we studied 60 patients in need for coronary artery bypass surgery. The left internal thoracic artery to LAD and radial artery to obtuse marginal artery $(\mathrm{OM})$ were used in 30 patients and the left internal thoracic artery to LAD and the SVG to OM will be used in the rest of them. All patients were under 70 years, ejection fraction was above or equal to $50 \%$, patients selected for radial conduit usage had negative Allen's test (the patient clenched their fist, and pressure applied to occlude both radial and ulnar arteries, after opening their fist and making sure that their hands were blanched, pressure was released on the ulnar artery, negative test indicates that the normal color of the hand is restored in 5-15 seconds which means that the ulnar artery is sufficient to supply the hand in the absence of radial artery), and the radial artery was used only to graft vessels with more than $70 \%$ stenosis and the distal diameter will be about $1.5 \mathrm{~mm}$ or more. Patients with renal failure, redo CABG or operated on emergency basis, cases with severe aortic calcifications, patients with positive modified Allen's test, peripheral vascular disease (e.g. Raynaud disease), and collagen disease were all excluded. Full laboratory investigations, chest X-ray, echo, electrocardiogram and coronary angiography were done for all the cases. All procedures were performed through a complete median sternotomy and single venous canulation. All cases were done on pump using cold blood cardioplegic arrest, the distal anastomoses were done during aortic cross clamping and the proximal anastomoses were done with aorta partially clamped.

This study includes 60 patients in need for coronary artery bypass surgery. The left internal thoracic artery (LITA) to LAD, and SVG to obtuse marginal artery (OM) were used in 30 patients and (LITA) to LAD, and the radial artery to OM were used in the rest of them. The choice of the type of conduit used for each patient was subjected to surgeon preference, and they mostly chose the radial artery for younger patients.

In the first group the radial artery was used as aortocronary bypass to OM, the RA was used only if it is more than $2 \mathrm{~mm}$ in diameter and free of any evident calcifications or atherosclerotic plaques, the RA harvest was done from the nondominant forearm at the same time during the harvesting of the left internal thoracic artery, harvesting RA was along with venae committantes using low strength electrocautery as an open method, the hemostasis during harvest was achieved with low strength cautery and metal clips, intravenous diltiazem infusion was started after induction of anesthesia and continued until the first post operative day when diltiazem was substituted and continued for at least 6 months.

In the second group the saphenous vein was used as aortocronary bypass to $\mathrm{OM}$, the saphenous vein harvest was done as an open method using sharp dissection and metal clips, harvesting of the saphenous vein was done at the same time during harvesting the left internal thoracic artery.

Post-operative ventilation time, ICU stay and hospital stay time were calculated. Post-operative complications including post operative myocardial infarction (defined by elevation of cardiac biomarker values "> $10 \times 99$ th percentile URL" in patients with normal baseline cTn values " $\leq 99$ th percentile URL". In addition, either new pathological Q waves or new LBBB, or angiographic documented new graft or new native coronary artery occlusion, or imaging evidence of new loss of viable myocardium or new regional wall motion abnormality), arrhythmia, low cardiac output (patients required inotropic support to maintain systolic blood pressure greater than $90 \mathrm{~mm} \mathrm{Hg}$ for at least 30 minutes, after optimizing preload and after load as well as correction of all electrolyte and blood gases abnormalities), bleeding, reopening, pleural effusion required drainage and wound -leg, radial and sternal-infection (serous, purulent discharge, wound gapping and deep sternal wound infection) were recorded. Electrocardiogram and echo were done for all patients at 2 weeks, and 6 months post operative. Patients were followed postoperatively after 6 months. Data collected included recurrent angina, acute myocardial infarction, congestive heart failure, any repeat coronary intervention such as percutaneous coronary intervention and redo $\mathrm{CABG}$, and any cardiac and non-cardiac related deaths. Recurrent angina was defined as recurrent chest pain in Canadian Cardiovascular Society class II or higher. Myocardial infarction was defined as an increase in cardiac specific troponin $\mathrm{T} \geq 0.03$ $\mu \mathrm{g} . \mathrm{L}^{-1}$ with or without new ST segment changes, presence of new $Q$ waves or new LBBB or imaging evidence of new regional wall motion abnormality. Congestive heart failure was defined as new onset shortness of breath, peripheral oedema associated with new systolic or diastolic dysfunction on the echocardiogram and/ or the appearance of new pleural effusion

The collected data were computerized and statistically analyzed using SPSS program (Statistical Package for Social Science) version 18.0. Qualitative data were represented as frequencies and relative percentages. Chi square test was used to calculate difference between qualitative variables. Fisher Exact test was used to calculate difference between qualitative variable when one of the cell had value less than 5 .

Quantitative data were expressed as mean \pm SD (Standard deviation). Independent $\mathrm{T}$ test was used to calculate difference between quantitative variables in normally distributed data in two groups. Mann Whitney test was used to calculate difference between quantitative variables in not normally distributed data in two groups. Pearson correlation coefficient used to calculate correlation between quantitative variables. $P$ value of $<0.05$ indicates significant results, $\mathrm{P}$ value of $<0.01$ indicates highly significant results. 


\section{Results}

Sixty patients were entered into the study. 30 patients underwent CABG using the SVG to graft the obtuse marginal $(\mathrm{OM})$ artery (group I), the other 30 patients underwent CABG using the radial artery to graft $\mathrm{OM}$ (group II). Demographic characteristics showed no difference regarding males to female's ratio, body mass index (BMI), but there was significant difference between the ages in the two groups.
There was one female in group one (3.3\%), and 4 females in the second group (13.3\%). The BMI in group I ranged from (20.76-37.88) with a mean value of $(29.56 \pm 3.98)$, and in group II it ranged from (18.43-42.45) with a mean value of (30.77 \pm 5.27$)$. Age in group I ranged from (45-68) with a mean value of $(57.07 \pm 5.90)$, and in group II it ranged from (27-67) with a mean value of $(48.8 \pm 9.4$. $)$ with a significant $p$ value $<0.001$

Table 1: Demographic data of the two studied groups

\begin{tabular}{|c|c|c|c|c|c|c|}
\hline Variable & \multicolumn{2}{|c|}{$\begin{array}{l}\text { Group I } \\
(n=30)\end{array}$} & \multicolumn{2}{|c|}{$\begin{array}{l}\text { Group II } \\
(n=30)\end{array}$} & $\mathbf{T}$ & $\mathbf{P}$ \\
\hline $\begin{array}{c}\text { Age : (year) } \\
\text { Mean } \pm S D \\
\text { Range }\end{array}$ & \multicolumn{2}{|c|}{$\begin{array}{c}57.07 \pm 5.90 \\
45-68\end{array}$} & \multicolumn{2}{|c|}{$\begin{array}{c}48.8 \pm 9.40 \\
27-67\end{array}$} & 4.08 & $<0.001^{* *}$ \\
\hline $\begin{array}{c}\text { BMI: }\left(\mathbf{K g} / \mathbf{m}^{2}\right) \\
\text { Mean } \pm S D \\
\text { Range }\end{array}$ & \multicolumn{2}{|c|}{$\begin{array}{c}29.56 \pm 3.98 \\
20.76-37.88\end{array}$} & \multicolumn{2}{|c|}{$\begin{array}{c}30.77 \pm 5.27 \\
18.43-42.45\end{array}$} & 1.10 & $\begin{array}{c}0.32 \\
\mathrm{NS}\end{array}$ \\
\hline Variable & No & $\%$ & No & $\%$ & $\chi^{2}$ & $\mathbf{P}$ \\
\hline $\begin{array}{c}\text { Sex: } \\
\text { Female } \\
\text { Male }\end{array}$ & $\begin{array}{c}1 \\
29\end{array}$ & $\begin{array}{c}3.3 \\
96.7\end{array}$ & $\begin{array}{c}4 \\
26\end{array}$ & $\begin{array}{l}13.3 \\
86.7\end{array}$ & 1.96 & $\begin{array}{c}0.16 \\
\text { NS }\end{array}$ \\
\hline $\begin{array}{c}\text { BMI: } \\
\text { Normal } \\
\text { Obese type I } \\
\text { Obese type II } \\
\text { Obese type III }\end{array}$ & $\begin{array}{c}4 \\
13 \\
10 \\
3\end{array}$ & $\begin{array}{c}13.3 \\
43.3 \\
33.3 \\
10\end{array}$ & $\begin{array}{c}3 \\
14 \\
6 \\
7\end{array}$ & $\begin{array}{c}10 \\
46.7 \\
20 \\
23.3\end{array}$ & 2.78 & $\begin{array}{l}0.43 \\
\text { NS }\end{array}$ \\
\hline
\end{tabular}

This table shows that there were no statistical significance differences between Group I and Group II in BMI or sex distribution. But there were statistical significance increase in mean age in Group II compared to Group I.

There was no significant difference between the two groups regarding diabetes, hypertension, hyperchlosterolemia. But there was significant difference between the numbers of smokers (group I: 5 non smokers, 22 exsmokers and 3 smokers), and (group II: 15 non smokers, 13 exsmokers and 2 smokers).

There was significant difference between the two groups regarding the number of distal anastomoses (group I: 11 patients had 2 and 19 patients had 3 distal anastomoses), and (group II: 4 patients had 2 distal anastomoses, 15 patients had 3, 9 patients had 4 and 2 patients had 5 distal anastomoses) with significant $P$ value of 0.002 . Also there was significant difference between the two groups with a $\mathrm{P}$ value of 0.005 regarding the cardiopulomary bypass (CPB) time, in group I it ranged from (40-115) minutes with a mean value of $(82.3 \pm 18.1)$ minutes, and in group II it ranged from (45-180) minutes with mean value of $(99.83 \pm 27.72)$ minutes.

Post-operative data showed no ECG changes or elevation of cardiac enzymes on both groups, 6 patients in group I (20\%) and 2 patients in group II developed atrial fibrillation (AF), 1 patient in group I $(3.3 \%)$ and 3 patients in group II $(10 \%)$ were in need for intropic support, no patient in group I required reoperation for bleeding versus 1 patient (3.3\%) in group II with no significant difference between the two groups. But there was a significant difference ( $p$ value 0.009 ) between the two groups regarding the total blood drainage in the first 24 hours, in group I it ranged from $(310-1100) \mathrm{ml}$ with a mean value of $(650.33 \pm 187) \mathrm{ml}$, and in group II it ranged from (350-1400) ml with a mean value of $(803.50 \pm 249.93) \mathrm{ml}$. Also there was a significant difference between the two groups regarding the need for blood transfusion (P value .04), with 9 patients received blood in group I (30\%) and 17 patients $(56.7 \%)$ in group II

Regarding wound infection 8 patients had leg wound infection $(26.7 \%)$ in group I, 7 patients $(23.3 \%)$ out of 26 patients had SVG harvesting in group II had leg wound infection, 2 patients in group II (6.7\%) had radial wound infection, and 4 patients in group I (13.3\%) and 5 patients in group II $(16.7 \%)$ had sternal wound infection with no significant difference between the two groups. But comparing the rate of leg wound infection in the two groups 15 cases (26.8) of 56 patients with SVG harvesting versus 2 cases $(6.7 \%)$ of 30 patents had radial artery harvesting showed significant difference (P value 0.03) 


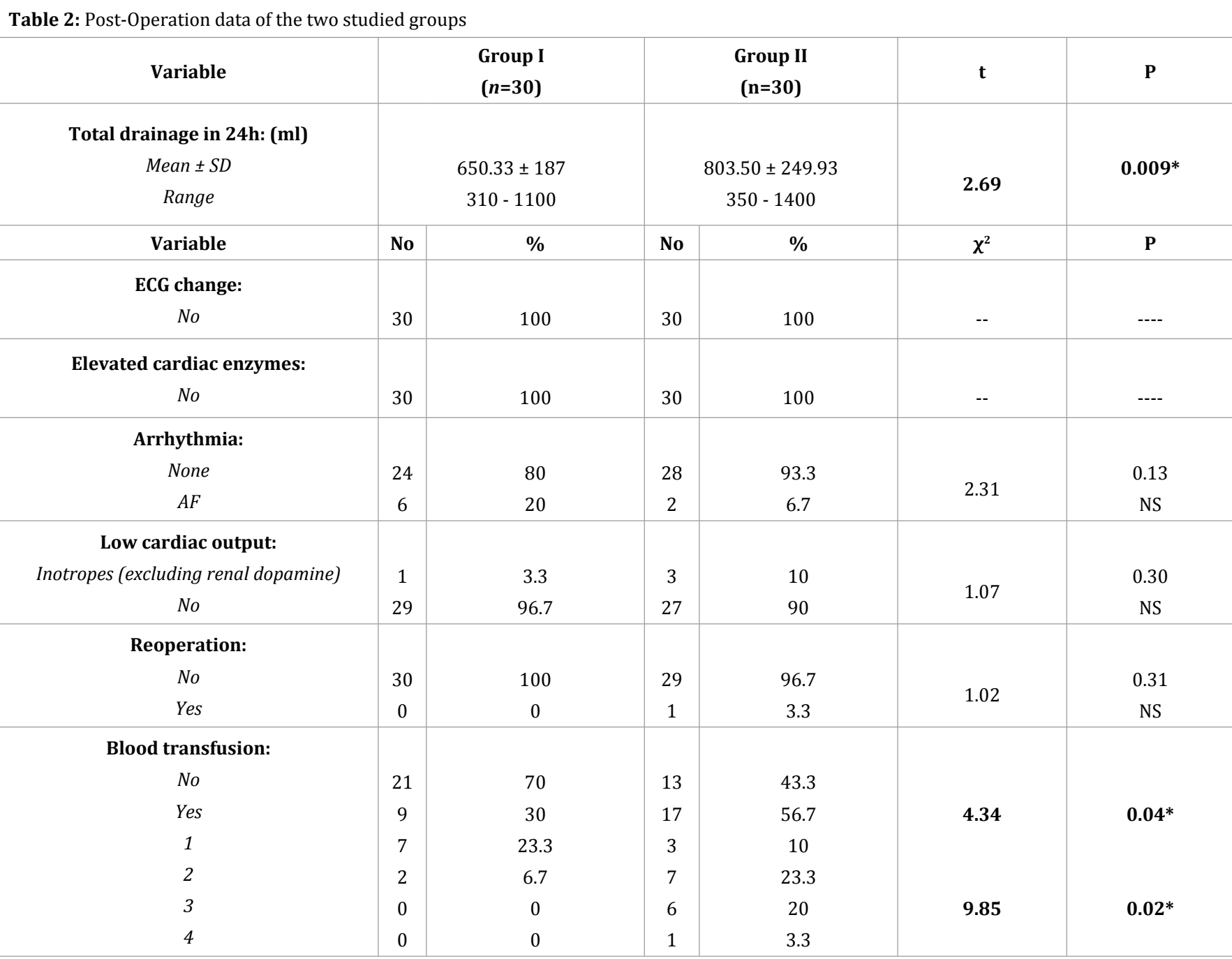

This table shows that there were no statistical significance differences between Group I and Group II in ECG, cardiac enzyme, arrhythmia, reoperation or low cardiac output but there were statistical significance increase in amount of total drainage, frequency of blood transfusion and amount of units in Group II compared to Group I.

\begin{tabular}{|c|c|c|c|c|c|c|}
\hline \multirow{2}{*}{ Variable } & \multicolumn{2}{|c|}{$\begin{array}{l}\text { Group I } \\
(n=30)\end{array}$} & \multicolumn{2}{|c|}{$\begin{array}{l}\text { Group II } \\
(n=30)\end{array}$} & \multirow{2}{*}{$\chi^{2}$} & \multirow{2}{*}{$\mathbf{P}$} \\
\hline & No & $\%$ & No & $\%$ & & \\
\hline \multicolumn{7}{|c|}{ Reoperation: } \\
\hline No & 30 & 100 & 29 & 96.7 & \multirow{2}{*}{1.02} & 0.31 \\
\hline Yes & 0 & 0 & 1 & 3.3 & & NS \\
\hline \multicolumn{7}{|c|}{ Sternal resuturing: } \\
\hline No & 30 & 0 & 30 & 0 & --- & --- \\
\hline \multicolumn{7}{|c|}{ Pulmonary complication: } \\
\hline No & 30 & 0 & 30 & 0 & --- & --- \\
\hline \multicolumn{7}{|c|}{ Pleural effusion need drainage: } \\
\hline No & 30 & 100 & 28 & 93.3 & 207 & 0.15 \\
\hline Yes & 0 & 0 & 2 & 6.7 & 2.07 & NS \\
\hline
\end{tabular}




\begin{tabular}{|c|c|c|c|c|c|c|}
\hline $\begin{array}{l}\text { Neurological complication: } \\
\text { No } \\
\text { Delayed recovery }\end{array}$ & $\begin{array}{c}0 \\
30\end{array}$ & $\begin{array}{c}0 \\
100\end{array}$ & $\begin{array}{c}1 \\
29\end{array}$ & $\begin{array}{c}3.3 \\
96.7 \\
\end{array}$ & 1.02 & $\begin{array}{c}0.31 \\
\text { NS }\end{array}$ \\
\hline $\begin{array}{c}\text { Renal complication: } \\
\text { No }\end{array}$ & 30 & 0 & 30 & 0 & --- & --- \\
\hline $\begin{array}{c}\text { GIT complication: } \\
\qquad \mathrm{No}\end{array}$ & 30 & 0 & 30 & 0 & --- & --- \\
\hline $\begin{array}{l}\text { Multi system failure: } \\
\qquad N o\end{array}$ & 30 & 0 & 30 & 0 & --- & --- \\
\hline $\begin{array}{l}\text { Readmission: } \\
\qquad \begin{array}{c}\text { No } \\
Y e s\end{array}\end{array}$ & $\begin{array}{c}28 \\
2 \\
\end{array}$ & $\begin{array}{c}93.3 \\
6.7 \\
\end{array}$ & $\begin{array}{c}28 \\
2 \\
\end{array}$ & $\begin{array}{c}93.3 \\
6.7 \\
\end{array}$ & 0 & $\begin{array}{c}1 \\
\text { NS }\end{array}$ \\
\hline $\begin{array}{l}\text { Leg wound infection: } \\
\qquad \begin{array}{c}\text { No } \\
\text { Yes }\end{array}\end{array}$ & $\begin{array}{c}22 \\
8 \\
\end{array}$ & $\begin{array}{l}73.3 \\
26.7\end{array}$ & $\begin{array}{c}(\mathrm{n}=26) \\
19 \\
7\end{array}$ & $\begin{array}{l}76.7 \\
23.3\end{array}$ & 0.01 & $\begin{array}{c}0.98 \\
\text { NS }\end{array}$ \\
\hline $\begin{array}{l}\text { Radial wound infection: } \\
\qquad \begin{array}{c}\text { No } \\
Y e s\end{array}\end{array}$ & ---- & ---- & $\begin{array}{c}28 \\
2\end{array}$ & $\begin{array}{c}93.3 \\
6.7\end{array}$ & -- & --- \\
\hline $\begin{array}{c}\text { Sternal wound infection: } \\
\text { No } \\
\text { Yes }\end{array}$ & $\begin{array}{c}26 \\
4\end{array}$ & $\begin{array}{l}86.7 \\
13.3\end{array}$ & $\begin{array}{c}25 \\
5\end{array}$ & $\begin{array}{l}83.3 \\
16.7\end{array}$ & 0.13 & $\begin{array}{c}0.72 \\
\text { NS }\end{array}$ \\
\hline
\end{tabular}

This table shows that there were no statistical significance differences between Group I and Group II in frequency of different complication.

Table 4: Comparison between radial and leg Wound infection among the two studied groups

\begin{tabular}{|c|c|c|c|c|c|c|}
\hline \multirow[t]{2}{*}{ Variable } & \multicolumn{2}{|c|}{$\begin{array}{l}\text { Radial Group I } \\
\qquad(n=30)\end{array}$} & \multicolumn{2}{|c|}{$\begin{array}{c}\text { Leg } \\
\text { All Group II } \\
(n=56)\end{array}$} & \multirow[t]{2}{*}{$\chi^{2}$} & \multirow[t]{2}{*}{$\mathbf{P}$} \\
\hline & No & $\%$ & No & $\%$ & & \\
\hline \multicolumn{7}{|c|}{ Wound infection: } \\
\hline No & 28 & 93.3 & 41 & 73.2 & \multirow{2}{*}{4.99} & \multirow{2}{*}{$0.03^{*}$} \\
\hline Yes & 2 & 6.7 & 15 & 26.8 & & \\
\hline
\end{tabular}

This table shows that there were no statistical significance differences between Group I and Group II in frequency of wound.

There was significant difference (P value .003) between the two groups regarding ICU stay, in group I it ranged from (1771 ) hours with a mean value of $(31.13 \pm 13.59)$, and in group II it ranged from (19-66) hours with a mean of $(40.20 \pm 12.51)$.

There was no significant difference between the two groups regarding hospital stay, readmission and follow up of patients of the two groups with ECG and echo showed no abnormality.

\section{Discussion}

This study includes 60 patients in need for coronary artery bypass surgery. The left internal thoracic artery (LITA) to LAD, and SVG to obtuse marginal artery (OM) were used in 30 patients and (LITA) to LAD, and the radial artery to OM were used in the rest of them. The choice of the type of conduit used for each patient was subjected to surgeon preference, and they mostly chose the radial artery for younger patients, 4 patients were included in the radial group because of harvesting of the SVG for them was inappropriate -2 patients had diabetic foot and the other two had deep venous thrombosis (DVT) -. Also, surgeons prefer to do total vascularisation for younger patients, which resulted in more distal anastomoses numbers in the radial group and more cross clamp time.

Postoperative data showed that 6 patients $(20 \%)$ had AF in group I and 2 patients (6.7\%) in group II with no significant difference between the two groups. The data for group I is similar to results obtained by Richard et al. and Laila et al. which showed that postoperative AF ranged from (10-65\%), but results in group II showed lower numbers which may be due to they are younger, as the older age has recorded to be one of the risk factors for postoperative AF [11-12]. 
There were one patient $(3.3 \%)$ in group I who needed intropic support versus 3 patients (10\%) in group II with no significant difference (P 0.03), 3 patients were females (1 from group I and 2 patients from group II) developed low cardiac output (LCOP) in the second postoperative day after the dose of B-blocker was given, and the third case in group II developed LCOP after excessive bleeding and tamponade followed by urgent exploration. These values, especially for group II, for LCOP are higher than reported by Khaled et al. in his study (2.4\%), but nearer to the results obtained by Renner et al. (11.2\%) [13-14].

The total blood loss in drains in the first 24 hours after surgery was $650 \pm 187 \mathrm{ml}$ in group I versus $803 \pm 249.93 \mathrm{ml}$ in group II which is statistically significant (P .009), with more blood transfusion in group II (17 patients $56.7 \%$ ) than in group I ( 9 patients $30 \%$ ), and these results are similar to that recorded by the society of thoracic surgeon and the society of cardiovascular anesthesiologists in their report in 2011 [15] Analysis for the risk factors for increased blood loss in group II showed that it was related to the increased CPB time in group II $(82.3 \pm 18.1$ minutes in group I versus $99.83 \pm 27.72$ minutes in group II), and these results were similar to results obtained by Alessandro et al., [16] but not to the study done by Giovanni et al. [17] in which the long CPB time was not included as a risk factor for postoperative bleeding.

No patient required re-exploration for bleeding in group I but 1 patient (3.3\%) underwent re-exploration in group II and the source of bleeding was discovered to be one of the proximal anastomoses, and these results was lower than that obtained by Alessandro et al. [16] in his study, but nearer to Keser et al. (2.73.5\%) [18].

ICU stay was ( $31.13 \pm 13.59)$ hours in group I, and $(40.2 \pm 12.51)$ in group II with significant (P 0.003). Analysis of these results showed correlation between ICU stay, total blood loss in the first 24 hours after surgery and blood transfusion required. And these results go with the study done by Giovanni et al., [17] so, it was not the choice of radial artery that affect the ICU stay, but the larger numbers of distal anastomoses and the longer CPB time in group II that result in more postoperative blood loss and longer ICU stay.

Table 5: Correlation between total drainage and blood transfusion, by pass time, ICU stay and hospital stay among the two studied groups

\begin{tabular}{|c|c|c|c|c|c|c|c|}
\hline Group & Variable & & $\begin{array}{c}\text { Cumulative } \\
\text { Bypass Time } \\
\text { (min) }\end{array}$ & $\begin{array}{l}\text { total drainage in the } \\
\text { 1st } 24 \text { hours (ml.) }\end{array}$ & $\begin{array}{c}\text { Number of } \\
\text { blood units } \\
\text { used }\end{array}$ & $\begin{array}{c}\text { Stay on ICU } \\
\text { (Hours) }\end{array}$ & $\begin{array}{c}\text { post ICU hospital } \\
\text { stay (days) }\end{array}$ \\
\hline \multirow{10}{*}{ Group I } & \multirow{2}{*}{$\begin{array}{c}\text { Cumulative Bypass Time } \\
\text { (min) }\end{array}$} & $\mathbf{r}$ & -- & $0.59^{* *}$ & $0.54^{* *}$ & $0.64^{* *}$ & -0.03 \\
\hline & & $\mathbf{P}$ & & 0.001 & 0.002 & $<0.001^{* *}$ & 0.86 \\
\hline & \multirow{2}{*}{$\begin{array}{c}\text { total drainage in the 1st } 24 \\
\text { hours (ml.) }\end{array}$} & $\mathbf{r}$ & $0.59^{* *}$ & $-\cdots$ & $0.76^{* *}$ & $0.73^{* *}$ & 0.08 \\
\hline & & $\mathbf{P}$ & 0.001 & & $<0.001$ & $<0.001$ & 0.69 \\
\hline & \multirow[t]{2}{*}{ Number of blood units used } & $\mathbf{r}$ & $0.54^{* *}$ & $0.76^{* *}$ & $-\cdots-\cdot$ & $0.59^{* *}$ & 0.03 \\
\hline & & $\mathbf{P}$ & 0.002 & $<0.001$ & & 0.001 & 0.90 \\
\hline & \multirow[t]{2}{*}{ Stay on ICU (Hours) } & $\mathbf{r}$ & $0.64^{* *}$ & $0.73^{* *}$ & $0.59^{* *}$ & $-\cdots$ & 0.11 \\
\hline & & $\mathbf{P}$ & $<0.001^{* *}$ & $<0.001$ & 0.001 & & 0.58 \\
\hline & \multirow{2}{*}{ post ICU hospital stay (days) } & $\mathbf{r}$ & -0.03 & 0.08 & 0.03 & 0.11 & --- \\
\hline & & $\mathbf{P}$ & 0.86 & 0.69 & 0.90 & 0.58 & \\
\hline \multirow{10}{*}{ Group II } & \multirow{2}{*}{$\begin{array}{c}\text { Cumulative Bypass Time } \\
\text { (min) }\end{array}$} & $\mathbf{r}$ & ---- & $0.85^{* *}$ & $0.82^{* *}$ & $0.59^{* *}$ & 0.17 \\
\hline & & $\mathbf{P}$ & & $<0.001$ & $<0.001$ & 0.001 & 0.36 \\
\hline & \multirow{2}{*}{$\begin{array}{c}\text { total drainage in the 1st } 24 \\
\text { hours (ml.) }\end{array}$} & $\mathbf{r}$ & $0.85^{* *}$ & --- & $0.91^{* *}$ & $0.75^{* *}$ & 0.30 \\
\hline & & $\mathbf{P}$ & $<0.001$ & & $<0.001$ & $<0.001$ & 0.11 \\
\hline & \multirow[t]{2}{*}{ Number of blood units used } & $\mathbf{r}$ & $0.82^{* *}$ & $0.91^{* *}$ & $---\cdot$ & $0.69^{* *}$ & .245 \\
\hline & & $\mathbf{P}$ & $<0.001$ & $<0.001$ & & $<0.001$ & .191 \\
\hline & \multirow[t]{2}{*}{ Stay on ICU (Hours) } & $\mathbf{r}$ & $0.59^{* *}$ & $0.75^{* *}$ & $0.69^{* *}$ & $-\cdots$ & $0.44^{*}$ \\
\hline & & $\mathbf{P}$ & 0.001 & $<0.001$ & $<0.001$ & & 0.02 \\
\hline & \multirow[t]{2}{*}{ post ICU hospital stay (days) } & $\mathbf{r}$ & 0.17 & 0.30 & 0.25 & $0.44^{*}$ & ---- \\
\hline & & $\mathbf{P}$ & 0.36 & 0.11 & 0.19 & 0.02 & \\
\hline
\end{tabular}

This table shows that there were positive statistical significance between cumulative bypass time and total drainage in 24 hours, blood transfusion units and duration of stay in ICU also there were positive significant correlation between total drainage in 24 hours and blood transfusion units and duration of stay in ICU and finally between number of blood transfusion units and ICU stay in both Group I and Group II. Also there were positive significant correlation between ICU stay and hospital stay in Group II.

15 patients had leg wound infection in both groups $(26.8 \%)$, which is similar to the study done by Heyman et al. in 2016 [19] that showed rate of leg wound infection ranged between (18$32 \%)$. Most patients had serous discharge only, with wound gapping in 2 patients in group I. radial wound infection occurred in 2 cases $(6.7 \%)$ in group II, which was in the form of mild serous discharge improved by frequent dressing, with significant difference between the rate of leg and radial wound infection (P 0.03). These results go with Mario et al. (2015) [20] and Nikolaos

et al. (2014) [21] showing that harvest site complications was lower in the radial group. Sternal wound infection occurred in 4 cases $(13.3 \%)$ in group I and 5 cases (16.7\%) in group II, all of them had mild serous discharge improved with frequent dressing, with no cases of deep sternal wound infection. Analysis for risk factors for leg wound infection showed strong relation with diabetes and obesity which is similar to results obtained by Raja et al in his study in (2015) [22] 


\begin{tabular}{|c|c|c|c|c|c|c|c|c|c|c|}
\hline \multirow{3}{*}{ Variable } & \multicolumn{4}{|c|}{ Group I hospital stay } & \multirow{3}{*}{$\mathbf{P}$} & \multicolumn{4}{|c|}{ Group II hospital stay } & \multirow{3}{*}{$\mathbf{P}$} \\
\hline & \multicolumn{2}{|c|}{$\begin{array}{c}\leq 7 \\
(n=20)\end{array}$} & \multicolumn{2}{|c|}{$\begin{array}{c}>7 \\
(n=10)\end{array}$} & & \multicolumn{2}{|c|}{$\begin{array}{c}\leq 7 \\
(n=21)\end{array}$} & \multicolumn{2}{|c|}{$\begin{array}{c}>7 \\
(n=9)\end{array}$} & \\
\hline & No & $\%$ & No & $\%$ & & No & $\%$ & No & $\%$ & \\
\hline \multicolumn{11}{|l|}{ Reoperation: } \\
\hline No & 20 & 100 & 10 & 100 & 1 & 20 & 95.2 & 9 & 100 & 0.51 \\
\hline Yes & 0 & 0 & 0 & 0 & NS & 1 & 4.8 & 0 & 0 & NS \\
\hline \multicolumn{11}{|c|}{$\begin{array}{l}\text { Pleural effusion need } \\
\text { drainage: }\end{array}$} \\
\hline No & 20 & 100 & 10 & 100 & 1 & 18 & 85.7 & 9 & 100 & 0.23 \\
\hline Yes & 0 & 0 & 0 & 0 & NS & 3 & 14.3 & 0 & 0 & \\
\hline \multicolumn{11}{|c|}{ Neurological complication: } \\
\hline \multirow{2}{*}{$\begin{array}{c}\text { No } \\
\text { Delayed recovery }\end{array}$} & 20 & 100 & 10 & 100 & 1 & 20 & 95.2 & 9 & 100 & 0.51 \\
\hline & 0 & 0 & 0 & 0 & NS & 1 & 4.8 & 0 & 0 & NS \\
\hline \multicolumn{11}{|l|}{ Readmission: } \\
\hline No & 20 & 100 & 8 & 80 & \multirow{2}{*}{$0.04 *$} & 20 & 95.2 & 8 & 88.9 & 0.52 \\
\hline Yes & 0 & 0 & 2 & 20 & & 1 & 4.8 & 1 & 11.1 & NS \\
\hline \multicolumn{11}{|l|}{ Leg wound infection: } \\
\hline No & 20 & 100 & 2 & 20 & \multirow{2}{*}{$<0.001^{* *}$} & 19 & 100 & 0 & 0 & ( \\
\hline Yes & 0 & 0 & 8 & 80 & & 0 & 0 & 7 & 100 & $<0.0011^{3 x}$ \\
\hline \multicolumn{11}{|c|}{ Radial wound infection: } \\
\hline \multicolumn{11}{|l|}{ No } \\
\hline \multirow[t]{2}{*}{ Yes } & 20 & 100 & 10 & 100 & 1 & 21 & 100 & 7 & 77.8 & 0.03* \\
\hline & 0 & 0 & 0 & 0 & NS & 0 & 0 & 2 & 22.2 & \\
\hline \multicolumn{11}{|c|}{ Sternal wound infection: } \\
\hline \multicolumn{11}{|l|}{ No } \\
\hline \multirow[t]{2}{*}{ Yes } & 20 & 100 & 6 & 60 & 0.002 & 21 & 100 & 4 & 44.4 & $<0.001 * *$ \\
\hline & 0 & 0 & 4 & 40 & $* *$ & 0 & 0 & 5 & 55.6 & \\
\hline
\end{tabular}

This table shows that there were statistical significance increase in frequency of long hospital stay among cases had leg wound infection in both studied groups. Also among readmitted patients in Group I and among cases had radial and sternal wound infection in Group II.

Hospital stay was $(7.6 \pm 3.17)$ days in group I, and $(6.9 \pm 2.12)$ in group II, with no significant difference. Analysis of the risk factors for patients with long hospital stay in both groups (defined as hospital stay $>7$ days) showed strong relation between long hospital stay and leg wound infection, which is similar to the results of the study done by Heyman et al. in (2016) [19].

2 patients $(6.7 \%)$ in group I were readmitted after discharge as they had gapped leg wound and wound debridement and secondary sutures were done for them. Two patients in group II were readmitted also, because of sternal wound discharge and pleural effusion that required insertion of intercostals chest tube. These data go with results of Kilic et al. (2017), [23] and Price et al. (2013) [24] showing that infection and pleural effusion are among the causes for readmission.

Patients in both groups did not develop myocardial infarction (MI), angina, ECG changes and echocardiographic changes after surgery and during the follow up period these good results was mostly because those patients were selected with good targets, good ejection fraction, and no comorbidities to avoid any factor that may affect the durability of the conduits. So, short term follow up showed no ischemic cardiac complications when both conduits (SVG and radial artery) were used, and these results are similar to the results of the study of Yamasaki et al. in 2016 [8].

\section{Conclusion}

Leg wound infection results in longer hospital stay. Follow up of both groups for 6 months after surgery showed the same results of both conduits (SVG and radial artery), but longer follow up will be needed to study the longevity of both conduits. 


\section{References}

1. Head SJ, Kieser TM, Falk V, Huysmans HA, Kappetein AP. Coronary artery bypasses grafting: Part 1 -the evolution over the first 50 years. European Heart Journal. 2013;34(37):2862-2872. doi: 10.1093/ eurheartj/eht330

2. Buxton BF, Galvin SD. The history of arterial revascularization: from Kolesov to Tector and beyond. Ann Cardiothorac surg. 2013;2(4): 419-426. doi: 10.3978/j.issn.2225-319X.2013.07.24

3. He GW. Arterial grafts: clinical classification and pharmacological management. Ann Cardiothorac Surg. 2013;2(4):507-518. doi: 10.3978/j.issn.2225-319X.2013.07.12

4. He GW, Taggart DP. Antispastic management in arterial grafts in coronary artery bypass grafting surgery. Ann Thorac Surg. 2016;102(2):659-668. doi: 10.1016/j.athoracsur.2016.03.017

5. Gaudino M, Crea F, Cammertoni F, Mazza A, Toesca A, Massetti M. Morpho-functional features of the radial artery: implications for use as a coronary bypass conduit. Ann Thorac Surg. 2014;98(5):18751879. doi: 10.1016/j.athoracsur.2014.06.101

6. Tranbaugh RF, Dimitrova KR, Friedmann P, Geller CM, Harris LJ, Stelzer P, et al. Radial Artery Conduits Improve Long-Term Survival After Coronary Artery Bypass Grafting. Ann Thorac Surg. 2010;90(4):11651172. doi: 10.1016/j.athoracsur.2010.05.038

7. Samano N, Geijer H, Liden M, Fremes S, Bodin L, Souza D. The notouch saphenous vein for coronary artery bypass grafting maintains a patency, after 16 years, comparable to the left internal thoracic artery: A randomized trial. J Thorac Cardiovasc Surg. 2015;150(4):880-888. doi: 10.1016/j.jtcvs.2015.07.027

8. Yamasaki M, Deb S, Tsubota H, Moussa F, Kiss A, Cohen EA, et al. 2016. Comparison of radial artery and saphenous vein graft stenosis more than 5 years after coronary artery bypass grafting. Ann Thorac Surg. 2016;102(3):712-719. doi: 10.1016/j.athoracsur.2016.02.107

9. Tatoulis J, Wynne R, Skillington PD, Buxton BF. Total arterial revascularization: A superior strategy for diabetic patients who require coronary surgery. Ann Thorac Surg. 2016;102(6):1948-1955. doi: 10.1016/j.athoracsur.2016.05.062

10. Hwang HY, Lee KH, Han JW, Kim KB. Equivalency of saphenous vein and arterial composite grafts: 5-year angiography and midterm clinical follow-up. Ann Thorac Surg. 2016;102(2):580-588. doi: 10.1016/j. athoracsur.2016.02.017

11. D’Agostino RS, Jacobs JP, Badhwar V, Paone G, Rankin JS, Han JM, et al. The society of thoracic surgeons adult cardiac surgery database: 2017 update on outcomes and quality. Ann Thorac Surg. 2017;103(1):1824. doi: 10.1016/j.athoracsur.2016.11.001

12. Al-Shaar L, Schwann TA, Kabour A, Habib RH. Increased late mortality after coronary artery bypass surgery complicated by isolated newonset atrial fibrillation: A comprehensive propensity-matched analysis. J Thorac Cardiovasc Surg. 2014;148(5):1860-1868.e2. doi: 10.1016/j.jtcvs.2014.05.020
13. Algarni KD, Maganti M, Yau TM. Predictors of low cardiac output syndrome after isolated coronary artery bypass surgery: Trends over 20 years. Ann Thorac Surg. 2011;92(5):1678-1684. doi: 10.1016/j. athoracsur.2011.06.017

14. Renner A, Zittermann A, Aboud A, Pühler T, Hakim-Meibodi K, Quester $\mathrm{W}$, et al. Coronary revascularization in diabetic patients: Off-pump versus on-pump surgery. Ann Thorac Surg. 2013;96(2):528-534. doi: 10.1016/j.athoracsur.2013.04.063

15. Ferraris VA, Brown JR, Despotis GJ, Hammon JW, Reece TB, Saha SP, et al. 2011 Update to the society of thoracic surgeons and the society of cardiovascular anesthesiologists blood conservation clinical practice guidelines. Ann Thorac Surg. 2011;91(3):944-982. doi: 10.1016/j. athoracsur.2010.11.078

16. Vivacqua A, Koch CG, Yousuf AM, Nowicki ER, Houghtaling PL, Blackstone $\mathrm{EH}$, et al. Morbidity of bleeding after cardiac surgery: Is it blood transfusion, reoperation for bleeding, or both?. Ann Thorac Surg. 2011;91(6):1780-1790. doi: 10.1016/j.athoracsur.2011.03.105

17. Mariscalco G, Gherli R, Ahmed AB, Zanobini M, Maselli D, Dalén M, et al. Validation of the european multicenter study on coronary artery bypass grafting (E-CABG) bleeding severity definition. Ann Thorac Surg. 2016;101(5):1782-1788. doi: 10.1016/j.athoracsur.2015.10.028

18. Kieser TM, Rose MS, Aluthman U, Narine K. Quicker yet safe: skeletonization of 1640 internal mammary arteries with harmonic technology in 965 patients. Eur J Cardiothorac Surg. 2014;45(5):e14250. doi: 10.1093/ejcts/ezu024

19. Luckraz H, Kaur P, Bhabra M, Mishra PK, Nagarajan K, Kumari N, et al. Endoscopic vein harvest in patients at high risk for leg wound complications: A cost-benefit analysis of an initial experience. Am J Infect Control. 2016;44(12):1606-1610. doi: 10.1016/j. ajic.2016.06.016

20. Gaudino M, Crea F, Cammertoni F, Massetti M. The radial artery: A forgotten conduit. Ann Thorac Surg 2015;99(4):1479-1485. doi: 10.1016/j.athoracsur.2014.11.045

21. Baikoussis NG, Papakonstantinou NA, Apostolakis E. Radial artery as graft for coronary artery bypass surgery: Advantages and disadvantages for its usage focused on structural and biological characteristics. J Cardiol. 2014;63(5):321-328. doi: 10.1016/j. jjcc.2013.11.016

22. Raja SG, Rochon M, Jarman JWE. Brompton Harefield infection score (BHIS): Development and validation of a stratification tool for predicting risk of surgical site infection after coronary artery bypass grafting. International Int J Surg. 2015;16(Pt A):69-73. doi: 10.1016/j. ijsu.2015.02.008

23. Kilic A, Magruder JT, Grimm JC, Dungan SP, Crawford T, Whitman GJ, et al. Development and validation of a score to predict the risk of readmission after adult cardiac operations. Ann Thorac Surg. 2017;103(1):66-73. doi: 10.1016/j.athoracsur.2016.05.10

24. Price JD, Romeiser JL, Gnerre JM, Shroyer AW, Rosengart TK. Risk analysis for readmission after coronary artery bypass surgery: Developing a strategy to reduce readmissions. J Am Coll Surg. 2013;216(3):412-419. doi: 10.1016/j.jamcollsurg.2012.11.009 